\title{
ОБРАЗ ЖІНКИ В МАНІФЕСТІ В. ДЕ СЕН-ПУАН «MANIESTE DE LA FEMME FUTURISTE. RÉPONSE À F.T. MARINETTI»
}

\author{
Данило Рега
}

Кандидат філологічних наук, доцент,

Кафедра світової літератури і порівняльного літературознавства, Прикарпатський національний університет імені Василя Стефаника (УКРАЇНА),

76018, м. Івано-Франківськ, вул. Шевченка, 57,

e-mail: danylo.reha@pnu.edu.ua

\section{РЕФЕРАТ}

Мета. Статтю присвячено аналізу образу жінки в маніфесті французької письменниці Валентіни де Сен-Пуан. Дослідницька методика. Для дослідження використано біографічний і зіставний методи дослідження. Використання цих методів дозволило проаналізувати взаємозв'язки між італійською і французькою літературами на початку XX ст., а також навести «причинність» появи першого маніфесту італійського футуризму в Франції. Результати. 3'ясовано специфіку поглядів французької представниці футуризму В. де Сен-Пуан щодо жінки та іï ролі в суспільстві, виходячи 3 загальних постулатів футуризму. Відзначені як спільні, так і відмінні типологічні риси в вищезгаданому аспекті. Наукова новизна. Вперше в вітчизняному літературознавстві звертається увага на творчість В. де Сен-Пуан, а також вперше перекладаються ії маніфести українською мовою. Практичне значення. Дана стаття може бути використана для подальшого дослідження історії і теорії футуризму, а також його зіставлень із іншими мистецькими напрямами. Наукові результати дослідження можуть бути використані під час написання курсових, дипломних і інших наукових проектів.

Ключові слова: образ, жінка, футуризм, фемінізм.

\section{THE IMAGE OF WOMAN ACCORDING TO «THE MANIFESTO OF FUTURIST WOMAN (RESPONSE TO F. T. MARINETTI)» BY V. DE SAINT-POINT}

\section{Danylo Reha}

\author{
Ph.D in Philology, Lecturer, \\ Department of World Literature and Comparative Literary Criticism, \\ Vasyl Stefanyk Precarpathian National University (UKRAINE), \\ 76018, Ivano-Frankivsk, 57, Shevchenka str., \\ e-mail: danylo.reha@pu.if.ua
}

\begin{abstract}
Aim. The article deals with the analysis of the image of a woman in the manifesto of the French writer Valentine de Saint-Point. Methods. In our research were used the following methods: biographical and comparative. The use of these methods made it possible to analyze the сщттусешщт between Italian and French literature at the beginning of XX century and also to indicate the «causality» of appearance of the first manifesto of Italian futurism in France. Results. In the article has been specified the views of the French representative of futurism V. de Saint-Point regarding woman and her role in society. based on the general principals of futurism. Also, have been noted both common and distinct typological features in the aforementioned aspect. Scientific novelty. For the first time in Ukrainian literary criticism is paid attention to the creative works of V. de Saint-Point and also for the first time her manifestoes are translated into Ukrainian language. The practical significance. The results of this paper can be used for further research of the history and theory of futurism, as well as its comparison with other artistic movements.
\end{abstract}

Key words: image, woman, futurism, feminism. 
У 1912 році вийшов у світ маніфест Валентини де Сен-Пуан французької поетеси, художниці, драматурга, однієї із перших представниць футуризму в Франції під назвою «Manifeste de la femme futuriste. Réponse à F. T. Marinetti» («Маніфест жінки-футуриста. Відповідь Ф. Т. Марінетті»). Це, водночас, була полеміка з Ф. Т. Марінетті у питанні ролі жінки в суспільстві, а також презентація власних поглядів щодо цієї проблеми. Футуризм був більше ніж напрям у мистецтві, адже його представники прагнули, щоб він проник в усі сфери людського життя: від літератури до культури споживання їжі, від музики до укладу життя. Відтак, футуризм відкритий до досліджень зусебіч, зокрема: А. Вудс [8], Д. Охана [2], К. Пінкус [4]) досліджують вплинув футуризму на ідеологію фашизму; М. Кірбі [1], В. Кірбі [1] та К. Пінкус [4] у своїх дослідженнях звертають увагу на модель футуристичного способу життя, на розвиток футуристичної моди та футуристичної кухні.

Насмілимося стверджувати, що футуризм серед усіх інших «-ізмів» першої третини XX століття був найбільш багатостороннім напрямом у свій сутності.

Різноманітні зовнішні та внутрішні контакти, що стимулювалися прихильниками футуризму, уможливлювали популяризацію останнього й впливати на літератури країн світу. Завдяки різного роду міжлітературним контактам футуризм швидко почав набирати популярність. Лідер італійського напряму Ф.Т. Марінетті, будучи адресантом, своїми численними поїздками й презентаціями прагнув вплинути на національні літератури, навернути митців країн із Свропи до лав футуризму.

Через географічну близькість Італії і Франції, багатовікові літературні контакти та взаємовпливи, а також зовнішні зв'язки Ф. Т. Марінетті 3 французькими літературними колами спричинили появу першого маніфесту футуризму не в Італії, а у Франції. Цю країну було обрано не випадково, адже Ф. Т. Марінетті провів свою молодість у Франції і до 1909 року писав винятково французькою мовою. Він мав романтичні взаємини з Розою Фатін дочкою багатого паші, яку хотів використати у власних інтересах, зокрема щоб батько Рози переконав редактора газети «Le Figaro» («Фігаро») надрукувати його маніфест. У той час Франція була найбільш прогресивною країною Свропи, вона диктувала моду, з легкістю приймала і поширювала все нове і тоді незнане, особливо в галузі мистецтва. У Парижі він зближується із членами журналу «La Plume» («Ручка»), які вплинули на тоді ще поетапочатківця i познайомили його із принципами білого вірша. Такі зовнішні впливи сприяли формуванню психології майбутнього поета-футуриста. Саме в журналі «La Plume» друкувалася і B. де Сен-Пуан. Можливо, вона була знайома 3 Ф. Т. Марінетті саме через спільну діяльність в межах журналу «La Plume».

Під впливом прочитання першого «Футуристичного маніфесту» Ф. Т. Марінетті, а також, що цілком вірогідно, через безпосереднє спілкування, французька футуристка Валентіна де Сен-Пуан видає у 1921 році маніфест «Manifeste de la femme futuriste. Réponse à F. T. Marinetti» («Маніфест жінкифутуриста. Відповідь Ф. Т. Марінетті»), у якому порушує водночас важливу, як на той час, і не близьку конкретно для італійських футуристів проблему - роль 
жінки у тогочасному суспільстві. Автор, на відміну від італійських футуристів, заявляє про єдність між чоловіком і жінкою: «Більшість жінок не $є$ ані начальниками, ані підлеглими для більшості чоловіків. Вони всі $€$ рівними. Вони всі заслуговують на презирство [...] Абсурдно ділити людство на чоловіків та жінок. Воно складається тільки із маскулінного та фемінного. Кожен супермен, кожен герой, незважаючи на те, наскільки він епічний, геніальний, сильний, $є$ величезним уособленням раси та епохи тільки тому, що він складається із жіночих і чоловічих елементів, фемінності й маскулінності» [6, с. 110] (тут і далі переклад наш. - Д. Р.). В. де Сен-Пуан доводить усупереч суспільній моделі італійського футуризму, а також моделі стосунків чоловіка та жінки, що остання може бути такою ж сильною, незалежною і відігравати таку ж важливу роль в історичному процесі, як і чоловік. Як приклад, вона перелічує відомих жінок, які залишили вагомий слід в історії людства: Жанна д’Арк, Жанна Ашетт, Клеопатра. Жінка, як і чоловік, може бути духовно сильною, що дасть їй змогу зрівнятися з ним або стати вище за нього.

На думку В. де Сен-Пуан, кожна жінка «повинна володіти не лише жіночими чеснотами, а й чоловічими; інакше вона є дівчиною, а не жінкою» $[6$, c. 110]. Новий тип жінки - це жінка 3 сильним характером, позбавлена романтичної складової своєї натури, здатна самотужки дати виклик суспільству.

Позаяк цей маніфест у своїй назві декларує «відповідь Ф. Т. Марінетті», то цікаво буде провести певні паралелі між думками В. де Сен-Пуан та італійським футуристом. Із дослідження А. Тешо «Italian Futurist Women» [7] можна зробити висновок, що якогось однозначного ставлення до жінок у Ф. Т. Марінетті не було: вона для нього була і жаданою (футуристичне есе «Come si seducono di donne» («Як спокусити жінку»), і винною у стримуванні світового прогресу. Як пише А. Тешо, цитуючи слова Ф. Т. Марінетті: «Кожна жінка $є$ особливою по-своєму, і кожна жінка може бути різною залежно від людини, яку вона любить. Жінка також може бути різною залежно від навколишнього середовища й атмосфери любові. Таким чином, кожна жінка пропонує себе в найрізноманітніших аспектах, але вона повинна бути прийнята такою, як вона є» [7, с. 4].

На тлі важливості фемінного в розвитку суспільства В. де Сен-Пуан виводить особливий образ жінки, який не відповідає традиційним поглядам. Сентиментальному жіночому началу вона протиставляє концепцію «sur-femme» («над-жінка»). Ця концепція схожа не тільки на ніцшеанську про надлюдину, але й типологічно подібна до розробленого італійськими футуристами образу «людини-кентавра», який також генетично пов'язаний із вченням Ф. Ніцше. Хочеться відзначити, що подібна концепція присутня, на думку, С. Павличко, у творчості української письменниці О. Кобилянської [3].

Цікавою є позиція В. де Сен-Пуан щодо такого явища, як фемінізм. У своєму маніфесті вона зазначає, що «фемінізм - це політична помилка. Фемінізм - це інтелектуальна помилка з боку жінки, помилка, яку іiі інстинкт згодом визнає» $[6$, с. 111$]$ й згодом додає, що «жінка повинна бути або матір'ю 
або коханкою. Справжні матері завжди будуть посередніми коханками, а коханки не будуть хорошими матерями через надлишок чеснот» [6, с. 112].

У 1913 році В. де Сен-Пуан видає доповнення до свого дебютного маніфесту під назвою «Manifeste Futuriste de la Luxure» («Футуристичний маніфест пристрасті»). Цілком ймовірно, що рік різниці між виходом першого маніфесту В. де Сен-Пуан і цього доповнення був для авторки вкрай важким, адже, як свідчать перші слова цього документу: «Це відповідь нечесним журналістам, які перекручують фрази, щоб висміяти Ідею; жінкам, які думають лише про те, як я наважилася про все це сказати; тим, хто вважає, що Похіть це не що інше, як гріх; тим, хто знаходить пристрасть гріхом, так само як у Гордості бачимо Марнославство» [5, с. 130].

У цьому доповненні до основного документу, авторка продовжує розглядати жінку на одному рівні із чоловіком, а також, як і інші представники футуризму, вводить поняття «культу тіла»: «Ми повинні свідомо бажати тіла, як і будь-якої іншої речі», «ми повинні ввести пристрасть у твори мистецтва» [5, с. 132]. Зазначимо, що в подальшому еротизм як модус любовної моделі футуризму досить по-різному буде використовуватися на практиці представниками футуризму інших країн Європи, головно це стосується слов'янського футуризму (Росія, Україна, Польща). На думку В. де Сен-Пуан, пристрасть $є$ рушійною силою світового прогресу та невід'мною частиною жінки.

Загалом, два маніфести В. де Сен-Пуан охоплюють ще один соціальний аспект першої третини XX ст. - роль жінки в суспільстві. Те, що представниця французького футуризму розглядала жінку як рівню чоловікові, тим самим протиставляючи власні футуристичні моделі італійським, пояснюється не тільки самою особою автора (фемінний тип наратора), а й тим, що у Франції після революції 1871 р. свобод стало більше, жінка стала відігравати важливу роль у суспільстві порівняно $з$ попередніми історичними епохами, відтак В. де Сен-Пуан передбачає проблему гендеру, тому розглядає суспільну модель футуризму крізь призму суспільнотворчої функції жінки, а також модель стосунків між чоловіком і жінкою в цій площині.

В. де Сен-Пуан обстоювала ідею розвитку та взаємодії чоловічого та жіночого начал у процесі розвою тогочасного суспільства, і саме в такій кооперації французька футуристка вбачала сенс футуризму. Безумовно, що саме через контактні зв'язки був даний старт футуризму в цій європейській літературі, але він у ній не прижився. Безпосередньо контактуючи 3 французькою літературою, Ф. Т. Марінетті намагався утвердити футуризм у Франції, проте ані його публічні виступи, ані протекція французьких футуристів, не забезпечили потрібного ефекту. В. де Сен-Пуан написавши «Маніфест жінки-футуриста» i «Футуристичний маніфест пристрасті» під впливом першого маніфесту Ф.Т. Марінетті, все ж полемізує із ним, таким чином не погоджуючись із питанням ролі жінки в суспільстві. Якщо Ф. Т. Марінетті вважав, що жінка не повинна приймати участі у формуванні суспільства, вона позбавлена «маскулінної» сили, відтак вона апріорі не здатна перебувати із чоловіком на одному суспільному рівні, то В. де Сен-Пуан закликала до повного рівноправ'я між чоловіком і жінкою, в чому вбачаємо 
типологічну відмінність щодо одного 3 ключових понять між двома футуризмами. Понад те, француженка бачила відмінний від Ф. Т. Марінетті сенс самого футуризму.

\section{ЛІТЕРАТУРА}

1. Kirby M., Kirby V. Futurist Performances. New York : PAJ publications, 1986. 336 p.

2. Ohana D. The Futurist Syndrome : Volume III of the Nihilist Order. Sussex Academic Press, Hardcover, 2010. 206 p.

3. Павличко С. Фемінізм. Київ : Вид-во Соломії Павличко «Основа», 2002. С. 218-228.

4. Pinkus K. Futurism: Proto Punk? The Niuean Pop Cultural Archive. Дата оновлення : 10.01.2020. URL: https://www.unknown.nu/futurism/protopunk.html (дата звернення: 14.01.2020).

5. Saint-Point V. Futurist manifesto of Lust. Futurism: an anthology. New Heaven \& London : Yale University Press, 2009. P. 130-133.

6. Saint-Point V. The Manifesto of Futurist Woman (response to F. T. Marinetti). Futurism : an anthology. New Heaven \& London : Yale University Press New, 2009. P. 109-113.

7. Tesho A. Italian Futurist Women. Forum on Public Policy : A Journal of the Oxford Round Table 5. No.1. P. 1-18. Дата оновлення : 10.01.2020. URL: https://www.thefreelibrary.com/Italian+futurist+women.-a0253058151 14.01.2020).

8. Woods A. Italian Futurism and Fascism. How an artistic trend anticipated a counterrevolutionary tendency // In Defence of Marxism. Дата оновлення: 10.01.2020. URL : http://www.marxist.com/italian-futurism-fascism.htm (дата звернення: 14.01.2020).

\section{REFERENCES}

1. Kirby, M. and Kirby, V. (1986), Futurist Performances, PAJ publications, New York, 336 p. (in English).

2. Ohana, D. (2010), The Futurist Syndrome: Volume III of the Nihilist Order, Academic Press, Hardcover, Sussex, 206 p. (in English).

3. Pavlychko, S.D. (2002), Feminism [Feminism], Osnova, Kyiv, 322 p. (in Ukrainian).

4. Pinkus, K., "Futurism: Proto Punk?", available https://www.unknown.nu/futurism/protopunk.html (in English).

5. Saint-Point, V. (2009), "Futurist manifesto of Lust", in Rainey, L., Poggi, Ch., Wittman, L. (Ed.), Futurism: an anthology, Yale University Press, New Heaven \& London, pp. 130-133 (in English).

6. Saint-Point, V. (2009), "The Manifesto of Futurist Woman (response to F.T. Marinetti)", in Rainey, L., Poggi, Ch., Wittman, L. (Ed.), Futurism: an anthology, Yale University Press, New Heaven \& London, pp. 109-113 (in English).

7. Tesho, A. (2010), «Italian Futurist Women», Forum on Public Policy: A Journal of the Oxford Round Table 5, No. 1, Summer, available at: https://www.thefreelibrary.com/Italian+futurist+women.-a0253058151 (in English).

8. Woods, A. (2003), «Italian Futurism and Fascism. How an artistic trend anticipated a counterrevolutionary tendency», In Defence of Marxism, available at: http://www.marxist.com/italian-futurism-fascism.htm (in English). 